\title{
Hansonella: The Morphology of a Modern Folk Tale
}

Jennifer Rutherford

\section{(2) OpenEdition}

\section{Journals}

\section{Electronic version}

URL: http://journals.openedition.org/transtexts/256

DOI: $10.4000 /$ transtexts.256

ISSN: 2105-2549

\section{Publisher}

Gregory B. Lee

\section{Printed version}

Date of publication: 1 December 2008

Number of pages: 114-129

ISSN: 1771-2084

\section{Electronic reference}

Jennifer Rutherford, «Hansonella: The Morphology of a Modern Folk Tale », Transtext(e)s Transcultures 跨文本跨文化 [Online], 4 | 2008, Online since 15 October 2009, connection on 20 April 2019. URL http://journals.openedition.org/transtexts/256 ; DOI : 10.4000/transtexts.256 


\title{
Hansonella: \\ The Morphology of a Modern Folk Tale
}

\author{
JENNIFER RUTHERFORD
}

In this essay I'm interested in the retroactive invention of Hansonella, a fairy-tale heroine created to assimilate the Australian nation's racist excess. I suggest here, that the fairy story - an essentially conservative and mythologising narrative - provided the retroactive means for the Australian nation to internalise and narrativise the emergence of a populist far-right party in Australia in the1990's. Intense antipathy to indigenous Australians and non-Anglo migrants has been integral to Australia's culture and history, but in white mythology, Australia is a culture of an enhanced generosity and goodness. Elsewhere I have called this fantasy structure the Australian Good, and argued that the fantasy of Australia as a good and neighbourly nation repeats and frames a disparate set of cultural practices, discourses and historical epochs. The underbelly of this fantasy of the good nation has been the dispossession of indigenous Australians, The White Australia Policy, the assimilation practices of the twentieth century, a pronounced antipathy towards the feminine and the intellectual, and the continued cultural policing of traits that carry the stain of difference.

"In modern Athens the vehicles of mass transportation are called metaphorai. To go to work or to come home, one takes a "metaphor" - a bus or train. Stories could also take this noble name: everyday they travel and organise places. They select and link together; they make sentences and itineraries out of them. They are spatial trajectories"

Michel de Certeau, The Practice of Everyday Life 1

\footnotetext{
1 M. de Certeau, The Practice of Everyday Life, [trans. Steven. F. Rendall], University of California Press, Berkeley, 2002. p. 115.
} 
On the cover of my childhood copy of Perrault's Fairy Tales² Sleeping Beauty lies in a jewel-encrusted gown awaiting the prince's kiss, Little Red Riding Hood carries a basket of field mushrooms to grandmamma, and Puss parades elegantly cuffed oversized boots. Brocaded with a Gothic script and coloured in muted primaries of red, yellow and blue, the book promises a recessed time. Simply to view its cover is to recall the enchantment of those endlessly repeated tales and their enthralling patina of jewels, demons, magic and whiter-than-white princesses. But if one momentarily succumbs to nostalgia, other memories and thoughts quickly surface.

To see Puss in Boots is to remember not only the enchantment of a canny and mischievous cat, but also to recall an adolescent yearning to feel feet slip into oversized soft leather boots capable of transforming the constrained steps of an adolescent girl into the seven-league leaps of an o'er vaulting ego. In other words, it is to remember those youthful moments when the inequities of the fairy story registered as signifying real constraints on a sexed self. Today, I cannot view Little Red Riding Hood's innocent picture without being reminded of other versions of the tale. In one I particularly like, the girl outwits the wolf by answering his orality with a sardonic anality. In this older version of the story, Little Red Riding Hood escapes being devoured by the feminine ploy of pretending to need to go to the toilet. The girl makes off while the wolf is left waiting for his dinner, until in a final loss of dignity he calls out: "Little Red Riding Hood are you making a load?" I wonder what Bettlelheim ${ }^{3}$ would make of this displacement, in which the girl hero wins out by a witty deployment of faeces?

The young women of my generation were delighted by the discovery of such versions and by the contemporary rewriting of fairy stories by authors such as Angela Carter, who reversed the narrative and dramatis personae of fairy tales to provide girls with villainous and victorious models of femininity. For decades now, children have read Roald Dahl's wicked rewritings, in which heroes are horrid and villains sweet. This rewriting, dismantling, and redeployment of the fairy story has continued apace throughout the later decades of the twentieth century. The most startling version of this is perhaps His Dark Materials ${ }^{4}$ a trilogy in which Philip Pullman draws on elements of the fairy tale to introduce a generation of young readers to the death of God. Fractured fairy stories are the commonplace of 101 Creative Writing, the analysis of arch-narrative begins the teaching of many filmstudies courses, and the World Wide Web provides fan-fiction writers with an

\footnotetext{
2 C. Perrault, The Sleeping Beauty and Other Stories, W. H. Allen and Co., London, 1958.

3 See B. Bettelheim, The Uses of Enchantment: The Meaning and Importance of Fairy Tales, Knopf, New York, 1976.

4 P. Pullman, His Dark Material, Laurel Lead Random House, New York, 2003.
} 
endless opportunity to pervert or dismantle any tale that hints at a traditional form. But if the fairy story manifests today in splintered form, warping and wefting in and out of other newer and more complicated tales, the original stories, their narrative structures and dramatis personae, continue to sound in everyday life and to offer, at moments of crisis, the childhood comfort of a contained universe.

When Princess Diana died unexpectedly, a constellation of fairy stories was waiting in the wings to make sense of her death in a way nobody could have anticipated until the end of the story. As her body was transported through the streets of London on a catafalque bedecked with lilies and then ensconced on an island grave covered with flowers, she became a site of narrative intensity. In the days of excessive mourning following her death, stories and characters fused. She was Christendom and Islam, commoner and noble, rich and poor, femininity and masculinity, freedom and duty. Amongst all those profound structural antagonisms, Sleeping Beauty, Snow White and Cinderella kept flashing up and illuminating her as the beautiful princess endangered by the wicked stepmother; the impoverished princess awaiting transformation by the prince's recognition; and the sleeping princess awaiting the kiss that would break the spell and release her from death. It didn't matter that the tales called upon to make sense of her life scrambled the logic of real events ${ }^{5}$. At those moments when fairy-story narrative seizes hold of historical events it's already too late to raise issue with the logic of the story.

"Stories, whether everyday or literary," de Certeau suggests, "act as a means of mass transportation". ${ }^{6}$ In everyday life they circulate in populations and organise their itineraries. Such stories more powerful than their literary counterparts, have the capacity to give coherence to groups and to transport them into organised movements. It is these stories that lie in the shadow of literature proper: they lack concision and form, but in true story fashion, open up fictional spaces in which entire populations find residence. The crowd spontaneously organising itself in mourning Diana was like birds moving into formation in flight. The crowd enacted a mourning ritual which went against the grain of a long history of repressing the public expressions of mourning. ${ }^{7}$ Could those rhythmic acts - the gentle clapping that followed the catafalque as it passed by, the throwing of lilies - have been spontaneously orchestrated without the unconscious mobilisation of a story capable of organising very different people into the spontaneous enactment of a collective

\footnotetext{
5 See J. Rutherford, “Diana: The Hour of our Death" in Planet Diana: Cultural studies and Global Mourning, Re:Public, Research Centre in Intercommunal Studies, Nepean, 1997.

6 Certeau, p. 115.

7 See G. Gorer, Death, Grief and Mourning in Contemporary Britain, Arno Press, New York, 1965, and P. Ariès, Western Attitudes toward Death: From the Middle Ages to the Present, [trans. P. M. Ranum], John Hopkins, Baltimore, 1974.
} 
ritual?

I am interested in the everyday circulation of such stories and in their transformation into fictional spaces that have the power to mobilise mass movements. In Australia in 1996, one such story found its way into the storymachine of the mass media, and from there carried its 'hero' to parliament, to the head of a populist mass movement and political party, to prison, and ultimately to iconic status in the mythology of contemporary Australia. That story bears some uncanny resemblances to that of Princess Diana, and no doubt owes some of its narrative power to Diana's reignition of the fairy-tale figure of the princess suffering at the hands of a wicked queen and in sore need of rescue from a gallant prince. Australia in the late 1990's invented its own Antipodean Queen of Hearts. Her name is Pauline Hanson. I call her Hansonella.

In this essay I'm interested in the retroactive invention of Hansonella, a fairy-tale heroine created to assimilate the Australian nation's racist excess. I suggest here that the fairy story - an essentially conservative and mythologising narrative provided the retroactive means for the Australian nation to internalise and narrativise the emergence of a populist far-right party in Australia in the 1990's. Intense antipathy to indigenous Australians and non-Anglo migrants has been integral to Australia's culture and history, but in white mythology, Australia is a culture of an enhanced generosity and goodness. Elsewhere I have called this fantasy structure the Australian Good, and argued that the fantasy of Australia as a good and neighbourly nation repeats and frames a disparate set of cultural practices, discourses and historical epochs. The underbelly of this fantasy of the good nation has been the dispossession of indigenous Australians; The White Australia Policy; the assimilation practices of the twentieth century; a pronounced antipathy towards the feminine and the intellectual; and the continued cultural policing of traits that carry the stain of difference. ${ }^{8}$

Australia has just witnessed a decade in which racist antipathy has coloured both the policies and the cultural performance of the Federal government; the brutality of former years has been revisited and old rhetorics redeployed. John Howard's Liberal government proved remarkably adept at combining the performance of racial mastery with a rhetorical appeal to the fantasy of the good nation. On the eve of the 2007 federal election for example, Howard sent Australian troops into

\footnotetext{
8 J. Rutherford, The Gauche Intruder: Freud, Lacan and the White Australian Fantasy, Melbourne University Press, Carlton, 2000.
} 
indigenous communities in the interior declaring a 'National Emergency' to save Aboriginal children from child abuse. In the early years of his government however, the rhetorical deployment of racist mastery was out of his control.

Pauline Hanson's first appearance in the Australian media was undistinguished. In January 1996 she wrote a letter to The Queensland Times criticising the government for providing indigenous Australians with unfair privileges. At the time she was the Australian Liberal Party's federal candidate for the seat of Oxley - a safe labour seat in Ipswich, an industrial town in southern Queensland. She was also the proprietor of a well-known local fish-and-chip shop, and had been active in local politics for several years. Fearful that her outspoken racism would damage its electoral possibilities in the upcoming federal election, the Liberal Party disendorsed her. A month later she won the seat as an independent candidate, thrashing the Labour candidate, Scott, with a vote of $48.6 \%$ against his $39.4 \%$.

Looking at the footage taken of Hanson at the time, it's hard to fathom that such an evidently unsophisticated woman would come to wield such extraordinary political influence. Within 12 months she was the leader of a national party challenging both the Liberal and Labour Parties, and was widely regarded as the most influential politician in Australia. ${ }^{9}$ Within five years, the Liberal Prime Minister John Howard would secure electoral victory for his flagging Liberal government by mobilising a phantasmagoria of invading foreigners modelled on Hanson's own fantasies and policies. The most noted example of this is the infamous "Children Overboard Affair", in which Immigration Minister Philip Ruddock declared to the media that an incident had occurred in which illegal immigrants on a sinking ship had thrown their children overboard. Photos purportedly representing this were provided to the media even though the Government knew the claims to be unfounded. In fact, the photos represented children in the sea after their boat had sunk. The government used the images to inflate public antagonism to refugees and to parade a masterly refusal to allow such villains to enter the country. Howard's electoral campaign deployed one key sentence: "We will decide who comes into this country and the circumstances in which they come", a transposition from the conditional to the active voice of a famous sentence of Hanson's. In the space of just a few years, Hanson, who had been initially disendorsed for racism by the Liberal Party, succeeded in regalvanising and relegitimising Australia's historical racial antipathy and xenophobia to the extent that it determined the racial politics of a decade of Australian Liberal rule.

\footnotetext{
9 See I. E. Deutchmann and A. Ellison, "A Star is Born: The roller-coaster ride of Pauline Hanson in the News" in Media, Culture E Society, Vol. 21, No. 1, 1999, pp. 33-50.
} 
Initially, Hanson's sudden rise to ascendancy produced panicked disbelief on both sides of the political spectrum. In September 1996, she delivered a maiden speech to Federal Parliament in which she positioned herself as an ordinary battler, an iconic figure in white Australia's colonial mythology. She described herself: "Not as a polished politician but as a woman who has received her share of life's knocks," and claimed to be speaking from the vantage point of common sense. While for a European sensibility this appeal to ordinariness and common sense might seem counter-intuitive, it has a long history in white Australian nationalist mythology, which valorises ordinariness as the defining trait of a culture levelled by its origins in exile and incarceration. Hanson argued that white Australians were suffering a reverse racism. "Fat cats, Aboriginals, multiculturalists and politicians" were the profiteers of an industry which deployed the moral rhetoric of reconciliation to defend the privileges of a black minority. Taking in her sweep single mothers, globalisation, indigenous and ethnic minorities, she evoked the glory days of the White Australia policy when Prime Ministers championed whiteness and blood ties. Australia, she argued, "was in danger of being swamped by Asians. Of course I will be called racist," she said, "but if I can invite whom I want into my home then I should have the right to have a say in who comes into my country."10

The response to Hanson's maiden speech was electric. For the many Australians who had participated and benefited from Australia's colonial practices, Hanson's was a speech they were longing to hear. In April 1997 she launched the political party One Nation, and by June 1998, had achieved the staggering victory of seizing 11 seats in the Queensland state election. But Howard, a cunning and pragmatic politician, apprehended the mass support for Hanson's racist views, and moved the racial politics of the Liberal Party far right. He was able to absorb Hanson's constituency by incorporating and staging the fantasises that interpellated it. With the Howard Government enacting One Nation policy and deploying its fantasies, the One Nation Party lost its rationale and disintegrated in a series of public brawls and scandals, culminating in Hanson and her advisor, David Ettridge, being imprisoned on August 212003 for electoral fraud. Hanson was a spent force politically, although her promise to restore the lost arcadia of white Australia had been made respectable under Howard's conservative rule. It was at this point that the media began an intense project of reassimilating Hanson.

In the years of Hanson's ascendancy, white Australia revealed its continued investment in the nationalist and racist fantasies of the past. It is this uncloaking of racism - in a momentary loss of camouflage - that I'm interested in here, and the way in which, in the aftermath of this visibility, the fairy story provided a narrative

10 P. Hanson, “Maiden speech”, Australian Federal Parliament, 10 September 1996. 
structure to reassimilate racist excess into the national fantasy.

Hansonella made an appearance long before Australian television audiences watched spellbound as week after week on prime-time television she danced, gowned and be-ribboned with the Stars. ${ }^{11}$ Back in 1996, her supporters were already translating concrete historical reality into myth; in fact, at every point in the development of the Hanson saga, her followers incorporated elements of the fairy tale into white Australian mythology in order to make sense of political events. This was not the only form of narrativisation or symbolic emplotment in play, and its significance only became fully evident at the 'end of the story'. I am going to analyse this process by focusing firstly on two periods in the development of One Nation, in which One Nation members drew on the fairy story to interpret political events. I am then going to identify two moments in which, in the aftermath of One Nation's demise, the media played a pivotal role in assimilating Hanson into Hansonella. The material I am drawing on derives from four years of extensive research interviewing and filming One Nation members from 1997 to 2001. I am also going to draw on Vladimir Propp's classic study of the fairy tale in order to illuminate key moments when Hanson segues into Hansonella. I should point out that this analysis is not of concrete, lived, historical reality, but rather of mythical reality, and as Roland Barthes wrote: "The function of myth is to empty reality: it is, literally, a ceaseless flowing out, a haemorrhage, or perhaps an evaporation, in short a perceptible absence." 12
\end{abstract}

Working with a limited sequence of tales, ${ }^{13}$ and without reference to cultural context, history, or paridigmatic structures of meaning, Propp developed a structural analysis, which despite many later theoretical challenges, continues to provide a useful starting point for the analysis of any fairy tale. As Allan Dundes writes in the introduction to the second edition of the English translation of Morphology of the Folk Tale: "Clearly structural analysis is not an end in itself! Rather it is a beginning." As a student of anthropology in the seventies, I honed my ethnographic skills by subjecting Rumplestiltskin and Rapunzel to Levi-Strauss' structural anthropology, so I confess to a certain nostalgic pleasure in returning here to an outmoded form of analysis to illuminate the narrative structure of Hansonella. I will not, however, be following Propp's morphology to the letter because Hansonella is not a fairy tale as such, but an unwritten mythology drawn on

11 Dancing With the Stars Australian TV Series, \& Network.

12 R. Barthes, Mythologies, [trans. Annette Lavers], Paladin Grafton Books, London, 1973, p 155.

13 Numbers 50-151 in A. N. Afanás'ev's collection Naródnye rússkie skázki. 
to make sense of political events, and does not, in itself, have any definitive textual form. What is surprising, however, is that despite the differences in material practice, history and context, Hansonella repeats many of the traditional structures identified by Propp.

My first glimpse of Hansonella was at a One Nation fund-raising event in Geelong in 1997. She was wearing a canary-yellow military jacket emblazoned with black ribbons and brass buttons. Sporting a bouquet of roses gilded with golden ribbon, she had flashes of gold on ears and fingers, brilliant vermilion nails, and hair on fire. Working the room like a bride at a wedding, Hanson moved from table to table bestowing her attention on each guest and in return receiving the gift of their desire. "I love you all," she kept saying, and they visibly loved her. Hanson was high on love, playing a sexual game with her male audience, which held out the promise of reconstituting their lost world. Her entourage of adoring men were being remade, reassuming their masculinity by virtue of her acceptance of their desire. Trading love for desire, Hanson was visibly replete, utterly feminine, utterly narcissistic and utterly phallicised. It was an extraordinary double act. Sustaining the desire of the men, and the identificatory adulation of the women, bestowing love on them all equally, and at the same time holding the microphone, she was both object and leader, princess and military commander. ${ }^{14}$ If this was a wedding, she was both the bride and the groom. But who was being married?

Propp's analysis of the fairy story focuses on the actions of the dramatis personae, and on what is being done rather than by whom and how. He identifies 31 functions (or actions) that repeatedly occur in fairy stories, hence their uniformity despite differences in content. For Propp, a function is "an act of a character, defined from the point of view of its significance in the course of an action"15 This focus on the significance given to acts is important for this analysis because academic and media interpretations of One Nation often failed to recognise the significance given to acts by One Nation followers. And yet, as we will see, these meanings ultimately held sway in the way Hanson was assimilated into national mythology.

Propp argues that a fairy tale begins with an initial situation in which the hero, his status and his family are introduced. He identifies seven functions that establish this preparatory part of the tale. While he gives numerous examples of variations of these functions, here, I will give them a very succinct summation. Firstly, a family

\footnotetext{
14 For an extended analysis of the relationship between erotic and political structures in the One Nation movement see J. Rutherford “One Love Too Many: The Undoing of Pauline Hanson" in Australian Journal of Politics and History, Vol. 47, No. 2., June 2001, pp. 192-208.

15 Propp, p. 21
} 
member absents themselves. Secondly, an interdiction is addressed to the hero who then, thirdly, violates this interdiction. Fourthly, the villain makes an attempt at reconnaissance, and fifthly, gains information about his victim. In the sixth function, the villain attempts to deceive his victim in order to take possession of him or his belongings, and lastly, the victim submits to deception and thereby unwittingly helps his enemy.

If we return to the events leading to Hanson's rise to public prominence, we can see that if we view them through the lens of her supporters, they fall readily into a fairy-tale structure. Her followers interpreted Hanson's initial letter to The Queensland Times as an act of defiance of an interdiction. For them, the parental guardians of Australia had absented themselves, leaving Australia in the hands of the 'fat cats', 'socialists' and the "Black Industry'. Defying the interdiction of the Liberal Party to keep quiet about the 'Black Industry', Hanson, the hero of the tale, rallied the common folk to defend the realm. Her magical gift was a golden tongue that had only spoken the truth. As I was told by one supporter: "They know Hanson's telling the truth... probably not as articulated as she should, but she's not capable of lying, because she hasn't got the 'nous' or the streets, or the political manoeuvring to lie so we know she's telling the truth. If politicians come out and attack her we can gauge them... it's like she's the barometer... That's what everyone's saying."16 With this magical gift she was able to cast off the bewitching rhetoric of the 'Black Industry' and reveal the truth to white Australia. The media, who were none other than the 'Black Industry' in disguise, flew in from the south to find whatever means they could to destroy her. One of the key turning points in Hanson's ascendancy occurred when television journalist Tracey Curio asked Hanson whether she was xenophobic. Unfamiliar with the term, Hanson responded: "Please Explain?" For her largely uneducated followers, this was interpreted as an attempt to shame Hanson, and by extension, all 'ordinary' Australians. Tantamount to a theft of their 'thing'17 - the Australian value of ordinariness - it provided a new impetus to rally to her defence.

In The Morphology of the Folk Tale, Propp argues that: "fairy tales posses a quite particular structure which is immediately felt and which determines the category even though we may not be aware of it."18 The wedding plays a key role in the fairy story; it often ends the tale when the hero is rewarded with the hand of the princess and the gift of the kingdom. The wedding in Geelong in 1997 was

\footnotetext{
16 State election, March 1998. Tape 2. See J. Rutherford, Ordinary People Archive, Film Australia, Sydney.

17 See S. Zizek, "Enjoy Your Nation as Yourself" in Tarrying With the Negative, Duke University press, Durham, 1993.

18 Propp, p. 6.
} 
precipitous, given the travails in store for its 'hero', but at that time Hanson had been elected to National Parliament, and had taken the nation by storm with the formation of the One Nation Party. For her followers this was an unimaginable end in itself. She had defied the Liberal Party's attempt to quieten her, named the villains that were besieging the country, stood up to the media who were the villains in disguise, rallied the realm and emerged victorious as the speaker of the 'Truth'. For them, Hanson and her golden tongue had won the hand of Australia the white princess.

This fairy-tale ending did not last long; in fact it was just the prelude to the herovictim's journey. For Propp, the fairy tale proper begins with the eigth function, when the villain causes harm or injury to a member of a family. It is this act of villainy that begins the movement of the tale, while earlier functions prepare the ground for this act. The seventh function, for example, in which the hero is deceived by the villain and thereby unwittingly helps him, introduces the theme of complicity between the hero and the victim. Function eight has many variations, such as seizing or taking away the magical agent, plundering, expelling or casting a spell upon someone, effecting a substitution, and so on. ${ }^{19}$ Villains in fairy tales also take on many disguises, so that the villain in one part of the story manifests in a different form in another.

For members of One Nation there were many villains, and they kept taking on new disguises. Hanson initially identified them as the thieves of the Australian way of life: the media, politicians, intellectuals, multiculturalists and the "Black Industry." But once Hanson became the head of a political party, villainy began to take on a new disguise.

"My first meeting with Pauline Hanson could only be described as gallant," David Oldfield told Who magazine. Seeing Hanson attacked in a Canberra restaurant by a vocal critic, Oldfield came to her rescue: "He was screaming abuse at her, and the women she was sitting with, calling them sluts, white trash, c--ts, all sorts of abuse ... I knew she needed help. She was being so courageous" 20 After this gallant entry, Oldfield who was then private secretary to the Liberal New South Wales MP, Tony Abbott, became Hanson's political advisor and, with the help of old friend David Ettridge, co-founded One Nation with Hanson. The structure of the party they devised was curious. It had only three members: those who thought they had joined the party were in fact only members of Pauline Hanson's Support group. It was this structure that eventually led to charges of electoral fraud and Hanson and

\footnotetext{
19 Propp, pp.30-36.

20 Who magazine, 23 June, 1997, p.26.
} 
Ettridge's imprisonment.

Having secured positions of power within One Nation, Oldfield and Ettridge then began to try and refashion it into a movement that accorded with their idea of a farright political organisation. If Hanson had mobilised neo-fascism in the raw, Oldfield and Ettridge wanted it cooked; together they made a rotten combination. Ettridge organised the party into cells and began fanning the already inflamed conspiracy fantasies of members with a new rhetoric about a new enemy - the white ant'. "Look for these people in your branches," he urged, "hunt them out and report them to head office." 21 According to many One Nation members, Ettridge expelled anyone who questioned the authority of the trio. As one member told me: "This fella, at any given time, he's got the power to pull whoever he likes out of the system. He just goes to the database and says "Gone!"22 For Oldfield, there was no room in the movement for divergent views: "One Nation people agree on things," he told me:

We have a party of people who largely all believe pretty much the same thing ... Where One Nation is concerned on issues and policies our votes are generally in the vicinity of $97 \%$. There is very little desire to go against what we all apparently believe in. It's clear we virtually all believe it because that's the way we vote." When asked about differences of opinion in the party he said: "We don't have them for long because we get rid of them pretty quickly.

Oldfield introduced a militaristic rhetoric into the movement, declaring a war to defend the nation: "I say [it's] a war. Its not a war where people are shooting at each other but it's a war where people's lives and their way of life and their children's future is at stake and that's the end result of a shooting war, and I say it's a war and we need people to fight it." 23

Under Oldfield's influence, Hanson began to make political statements that countered her earlier rhetoric of returning Australia 'to the people'. At one political rally she foolishly declared that democracy was 'mob rule', thus destabilising her own position as a leader able to voice the democratic will of 'her' people. In the perception of many of her supporters she had fallen from the position of goldentongued truth-speaker to a woman under the influence of the enemy.

I recorded numerous interviews with members of One Nation speaking about Oldfield's ensnarement of Hanson. Many men were evidently sexually outraged that 'their Lady' had been bewitched by a villain, who, as one man told me: "could

21 David Ettridge. Tape 70, Rutherford Archive.

${ }^{22}$ Interview Rooty Hill, Tape Rutherford Archive Tape 71.

${ }^{23}$ Interview with David Oldfield, Rutherford Archive, Tape 78. 
walk under a snake's belly with an umbrella up". ${ }^{24}$ Language used to describe Oldfield was often colourful, focusing on his sexual power over Hanson, but the language used to describe the relationship between Hanson and her supporters was often explicitly mythical. One interviewee said:

I think the Black Knight got in. And she couldn't tell the difference. I think she wasn't really a damsel, I think she basically couldn't tell the difference between the black Knight and the White Knight, because there were a lot of White Knights, there were a lot of good people in One Nation but the Black Knights basically came in and took the position of authority. ${ }^{25}$

This narrative occurred in a broader discussion, in which the interviewee was discussing why people in his community had joined the White Knights, a local chapter of the KKK. In the interview, the meaning of White Knight segues from designating members of the KKK to its fairy-tale connotation of a hero rescuing a damsel. If Hanson was initially the masculine hero of the tale, she had become the feminine victim in need of a seeker-hero to rescue her. Equivocating between these two positions, she was both the hero under the spell of the enemy, who would in time cast off bewitchment, and the damsel that the brotherhood of heroes must rescue. Here we can see the way the fairy story was called on to restabilise meaning at those moments when Hanson's promise to restore a lost world proved inadequate to unfolding complex social reality. At moments when the world view Hanson had promulgated revealed its symbolic inconsistency, the fairy tale was called on to restabilise traumatic reality into a familiar narrative structure. The fairy story was not alone in playing this role, conspiracy theories about international financiers and socialists, for example, also fulfilled a similar function. In one story in circulation, Oldfield himself was supposedly planted in One Nation by Fabian socialists and international financiers. Unlike these conspiracy theories, however, the fairy story held out the promise of a nostalgic return to happier times.

Like other far-right movements, One Nation was organised around the mobilisation of the memory of an imagined earlier time. For individuals unable to find a secure point of identification in their social structure, Hanson offered a coherent story that promised to stabilise social reality and deflect the ongoing trauma of real social displacement. The story that Hanson launched promised to restore both symbolic identity and traditional hierarchies to her followers. At the point when her symbolic consistency faltered, many of her followers sustained this narrative through new detours in the fairy story. For some, when Hanson's acts destabilised her own nostalgic morality, she became entangled within the tale as one of its villains. To

\footnotetext{
${ }^{24}$ Interview with One Nation Supporter, Rutherford Archive, Tape 75.

25 Interview with One Nation supporter, Rutherford Archive, Tape 76.
} 
many of her followers she became a crook, a thief and a politician. To others, she became a damsel, and a coterie of would-be heroes vied for the role of rescuing her. For others still, she remained the hero-victim suffering the necessary ordeals and tribulations of a hero on a quest. And Hanson's ordeals and tribulations fell all too easily into the trials of a hero-victim, dispatched into a world of villainy.

In an early interview, Stuart Hall wrote of the media: "we tell stories like we've told them before or we borrow from the whole inventory of telling stories....' ${ }^{26}$ I want to turn now to the way elements of the Australian media told stories that retroactively translated Hanson's ascendancy into the familiar narrative structures of the fairy story. Hanson's political decline was coloured by ugly political brawls, defections by key supporters, allegations of the appropriation of party funds, fears of bankruptcy, and eventually, conviction for electoral fraud. Once the fairy story has been activated, these events have the potential to fall all too readily into its narrative frame. In the fairy story, the victim-hero suffers a series of tribulations, ordeals and tests, until finally the villain is vanquished, the hero recognised and social order restored. When Hanson was imprisoned for electoral fraud and no longer a threat to the political status quo, she transformed from a vilified fish-andchip shop harridan - the media's favoured mode of representing her - into a herovictim in an Australian fairy story. It should be noted that white Australia does not have its own fairy stories, and Hansonella is perhaps the first attempt to generate a modern fairy story for white culture as distinct from the mythology of colonial culture.

In the days following her imprisonment, newspaper articles focused on her discomfort, on the personal tragedy of her imprisonment, and the unfairness of the sentence. Many media articles translated the issue of electoral fraud into an ordeal and test of endurance for the heroine of the story. Journalists reported Hanson's first night in custody, her first telephone call, her first family visits, her strip-searches, her medication, her fear and trembling, her relentless bravery and her messages of comfort and courage to supporters. We read of her sister's shock and horror in seeing the sartorially attentive Hanson reduced to a grey prison tracksuit, and of the brilliant red lipstick she had been forced to relinquish. Readers shared the indignity of her flannelette prison nightgown and meagre toilet bag, soap and toothpaste replacing vermilion nail polish and hair dye. As Propp writes, this is one of the tale's favourite elements, in which the hero is subject to ordeals of food and drink, tests of endurance, of strength and of fortitude. (Function 25) Traditionally this follows Function 24, in which a false hero makes unfound claims against the

\footnotetext{
26 S. Hall, "The Narrative Construction of Reality; an interview with Stuart Hall" in Southern Review, 17, March 1984.
} 
hero. ${ }^{27}$ According to the media - and Australian politicians - Hanson had been pursued relentlessly by her political opponents (Function 21) and unfairly charged by a false hero (Function 24 ).

In the media reportage following her imprisonment, there was little comparison of her sentence with similar sentences for acts of electoral or political fraud, but a great deal of rhetorical gesturing towards 'real criminals' who commit 'real crimes' and who the state refuses to imprison. Politicians from all political spectrums tumbled over each other in their eagerness to join their voices to 'the flood of sympathy' for Hanson that the papers reported. Immigration Minister Philip Ruddock, infamous for his treatment of detained refugees, declared it was: "very sad for Australia and for the political system." NSW Labour Premier Bob Carr argued that prisons exist for people who are a danger to society: "a danger to you and me and our families, when we're walking down the street." Hanson's crime, he claimed, was: "a crime without a victim." The Democratic Leader, Natasha Stott-Despoja, asked: would someone "Please Explain?"28 There was virtually no discussion or political analysis of the party structure that gave rise to 'the technicality' of registering Pauline Hanson's support group as party members, nor any analysis of why this dual-party structure had been developed, or to what end. This kind of discussion did take place in limited ways in small columns and opinion pieces in the weeks following her imprisonment, but these discussions paled into insignificance beside the headline-grabbing details of strip-searches, children's tears, songs of innocence and of a 'Lady' undone by a harsh and corrupt legal system. This was the real story. We were in the realm of Hansonella.

Locked in her prison cell singing 'Someday My Prince Will Come,' Hanson ascended into myth, forging a new synthesis between the poor working girl in need of a prince, and the political champion of an enslaved people who was herself enslaved by a heartless elite in cohorts with a corrupt judiciary. Never before had Hanson achieved this purely mythical status in which Labour, Liberal and Democratic politicians joined their voices with the shock-jocks to express sympathy for a 'Lady' so cruelly undone. ${ }^{29}$ In this context, the recirculation of old images of Hanson served to retroactively constitute her as an iconic and mythical figure. She reappeared as Hanson the queen draped in the Australian flag; as Hanson the femme fatale in a sequined red dress, glittering as she lifted her arms in an open salute to 'her people'; and Hanson the 'Aussie battler', manning the electoral booths

\footnotetext{
27 Propp, p. 60.

28 The Australian 22/8/2003 p. 2.

${ }_{29}$ For an earlier version of this analysis appears in J. Rutherford, "The Unusable F. Word, Fascism and the Australian Media", in Peter Manning [ed.], Social Alternative Special Issue, 2005.
} 
in her blue working-man's shirt. Responding to her gaol sentence, The Sydney Morning Herald retold her 'story' as the rise from barmaid to single mother, to fishand-chip shop redhead, to the political nemesis of the nation. In its headline 'Flame haired: Flame Out' Hanson was emptied of historical content and reconstituted as myth. ${ }^{30}$

No fairy story is complete, however, without a happy ending. One common prelude to the end of a fairy story is when the hero puts on new garments. "The girl," Propp writes, "puts on a magical dress and ornaments and suddenly is endowed with a radiant beauty at which everyone marvels." (Function 29) 31 This function follows Function 28, when after successfully completing a long ordeal, the hero is finally recognised. Released from prison after just three months of a threeyear term, Hanson re-entered the media spotlight redefined by her period of incarceration. Now able to speak for all Australians - she had rubbed shoulders with a few indigenous Australians 'inside' - Hanson's celebrity precluded any unseemly focus on her politics. Women's magazines vied for photo shoots of her post-prison makeover and by 2004 she was Dancing with the Stars. In the respectable Victoria newspaper The Age, Helen Razor wrote of her seduction by Hanson:

Pauline was reborn. Hanson was both shiny and benign. In series one, host Daryl Somers said of Hanson, "she may not be sitting in the Senate but she's still standing for us." "Speak for yourself," I said to the television, resentful that this body of ignorance had been exhumed and dressed up in hideous rhinestones. Whether it was the power of prime time, the high-powered schmaltz of Daryl or simply the sensual heat of the cha-cha, something inside me had melted. Hanson's radical journey from redneck to rumba princess sucked so many of us in. Oh yes, I thought, people can change for the better! Oh the power of dance. ${ }^{32}$

Dancing with the Stars was followed by Who Wants to be a Millionaire, Tod McKinney's Live Show and This is Your Life. In Australian terms, the red-headed princess and the white Nation were waltzing Matilda down the wedding aisle. That's Function 31: the hero is married and ascends the throne.

There are clear parallels between Hanson's One Nation Party and similar far-right movements internationally. In Europe, it has become clear that the phantasm of a

\footnotetext{
30 Sydney Morning Herald, 21 August 2003.

31 Propp, p. 63.

32 H. Razer, "Dancing with the Stars", The Age, 1 September 2005.
} 
tidal wave of invading foreigners has the capacity to reach hegemonic dimensions and to create popularly based mass movements able to utilise democratic processes for potentially barbarous ends. Far-right and fascist organisations have evolved, developing new discursive strategies and camouflages that effect a discursive separation of their contemporary agendas from the explicit racism and violence of the past. In this new rhetoric of the far right, the projection of a host of social and economic problems onto displaced and deterritorialised populations guises as a legitimate fear of loss of national sovereignty, identity and tradition. As Etienne Balibar points out in Politics and the Other Scene, 33 the only mass movements in Europe today are those organised around the theme of a rejection of the foreigner. Violence against these populations is intensifying as one European nation after another experiences the 'acting out' of these phantasmatic fears in outbreaks of violence and collective manifestations of racism. These movements look very different from traditional fascism, they have none of its overt signs - no swastikas, war cults or explicit anti-Semitism - but they share a family resemblance. ${ }^{34}$. Like their traditional forebears, they mobilise passions and fears around an ideal of national unity through the internal cleansing of foreign traits, and are organised around resentment of foreigners and displaced and stateless people. In this essay I have attempted to demonstrate the role that a traditional literary form can play both in the mobilisation of such a movement and in its assimilation into mainstream public life. Despite the apparent mutation and dissolution of such forms, their tenure on the collective imagination continues to sound. In Hansonella, complex social reality was eviscerated in the face of the nostalgic comfort and pleasure of a familiar story.

33 E. Balibar, Politics and the Other Scene [Trans. Daniel Hahn], Verso, London, 2002.

34 See U. Eco, Five Moral Pieces, [trans. Alastair McEwen], Secker and Warburg, 2001, pp. 65-88. 